\title{
Professional orientation of schoolchildren living in the agricultural region of Russia, based on social and pedagogical partnership
}

\author{
Tatiana Vlasova ${ }^{1, *}$, Valentina Abraukhova ${ }^{1}$, Evgenia Krasnova $^{1}$ \\ ${ }^{1}$ Don State Technical University, 1, Gagarina, sq., 344003, Rostov-on-Don, Russia
}

\begin{abstract}
The article deals with the analysis of professional orientation of schoolchildren, living in the agricultural region of Russia (on the example of Starocherkasskaya village of the Rostov region). The following tasks were solved: the model of spiritual and ontological partnership in a small rural school was substantiated and implemented, diagnostics and analysis of value orientations of general stakeholders were carried out in the process of employment in a rural settlement, and the features of professional orientation of rural schoolchildren are formulated. The study was conducted from 2008 to 2018, the main goal of which was to meet the needs of young people in their professional and personal vocations, which does not contradict the native values of Russia. The article substantiates the basic indicator of professional orientation of schoolchildren - "trust", which permeates the communication of general stakeholders in the agricultural sector. The main areas of life that are the basis of professional orientation of school - family-community, spiritual-cultural, vocational, social, individual, allowed young people to be realized, as in the agricultural sector and outside it in space of a Russian village.
\end{abstract}

\section{Introduction}

UNESCO recommends vocational guidance for young people based on two basic conditions: self-determination of a person and the needs of society. At the same time, it becomes obvious that these conditions in the modern world can be either complementary to each other in developed foreign countries, or contradictory. This antinomy is especially evident in those societies that do not have the appropriate economic infrastructure to meet the individual needs of the younger generation associated with the choice of profession. Such agglomerations are agricultural regions in developing countries, including the Rostov region of the modern Russian Federation, which actualizes the formulation of this problem.

On the other hand, it should be noted that the task of professional orientation has not been new since the beginning of the twentieth century, since the right choice depended not so much on the personal development of a person as on the economic development of countries. For example, in the United States, the traditional approach to career guidance included the following components: analysis of the teenagers` abilities, their acquisition of

\footnotetext{
* Corresponding author: tvlasova@rambler.ru
} 
knowledge in the field of future professions and mastery of reflexive skills (F. Parsons). At the same time, the Russian experience followed in its "fairway", specifying and developing all kinds of programs, diagnostic protocols, conversations and other forms of work with students, which in a stable society partially solved the problem of professional orientation of students.

In the conditions of Russia's transformation, the requests of general stakeholders are not sufficiently taken into account, as well as in the agricultural sector, which causes the problem to be posed in an innovative way of research, that is, the development and implementation of a model of schoolchildren ' professional orientation on the basis of social and pedagogical partnership (T. Vlasova, 2016; V. Abraukhova, 2018) [1, 2] of rural schools with families of pupils, with cultural and spiritual Centers of the village. The choice of the future profession by rural schoolchildren happens, on the one hand, against an indefinite sense of existence of the rural family in the Russian village in which the agricultural sector cannot meet the today's youth labor vocation. On the other hand, it sets ambitious goals in terms of the digital economy, multimedia orientations and virtualization of various spheres of life [3, 4]. We believe that the degree of coincidence of professional orientation of schoolchildren and family values is a basic indicator of their future labor success, since the rise of agricultural production, at least, depends on the human factor, that is, on how young people are ready to return to their native places of residence, which actualizes this study.

\section{Review of scientific sources}

Logical and semantic analysis of sources in foreign science we carried out in separate blocks. Given, first of all, the high level of economic development of countries and the agricultural sector, scientists (Linda Hargreaves, Rune Kvalsund, Maurice Galtona,) offer innovative forms of education in rural schools, as there arises the need to optimally approximate them to urban conditions, including the organization of vocational work with young people. Similar problems exist in rural communities in the United States, which, according to some researchers, is appropriate to solve through the "Play Streets" method, aimed at improving the physical development of rural children. Public organizations in lowincome rural communities (representatives of African-Americans, Indians, Hispanics, or white, non-Hispanic groups) received mini-grants in 2017 to implement safe streets for children to walk [5]. A number of scholars suggest that vocational guidance should be provided to high school students in a Swedish village using various social and cultural resources, describing, for example, that relatives, including siblings, can help young people from the village to study in cities, in prestigious educational institutions, which directs high school students from rural schools to choose a profession in the non-agricultural sector. The same study describes the role of cultural resources that also influence institutional recognition [6]. Opposite trends related to finding the most favorable educational and environmental conditions for their children are observed by scientists in the UK, who write that many young families are puzzled by moving to rural areas where, in their opinion, there is a more favorable environmental situation. However, it is necessary for such a suburb to have a well-developed educational infrastructure. At the same time, families invest significant funds in these projects [7]. In practice, it is necessary to take into account family values both when determining the educational line for their children and when determining their future profession.

Of great interest for this study are the articles of scientists, which reveal the features of rural schools, its prospects in developing countries, for example, in such countries as: Uganda [8], India [9], China [10-13]. In addition to the global trend of rural residents moving to work in cities, the articles note the stability of family values in these countries, 
which are based on religious beliefs, and they emphasize the role of family members living together in the village, which affects the decision to be engaged in non-agricultural work. For example, in developing China, a targeted state policy is being implemented to regulate family life, fertility, and the organization of education and vocational guidance for children in rural schools. According to scientists, the model of academic mobility differs in urban and rural areas, while "... as a result of market reforms, the level of education has become an important factor determining income, and since the 1990s, China has dramatically increased the return on school education, which is now comparable to the economy of Western countries" [12]. The economic performance is also affected by the variety of didactic forms and methods of education, and the availability of higher education for young people from the village [14-15]. At the same time, reality shows that rural schools in postSoviet countries, such as Hungary, tend to eliminate low-grade schools [16], since the population of villages moves to cities, there are no jobs in the agricultural sector. These trends are also typical for modern Russia, which actualizes the problem of professional orientation of Russian schoolchildren living in rural regions.

Domestic discourse on this issue is correlated with the above-mentioned studies, but they also have their own specifics. Thus, the $\mathrm{PhD}$ theses of Danilova M. A. and Kholmogorov (2010) present detailed models of professional orientation of rural schoolchildren based on the traditional, three-factor approach, which, as a rule, repeat similar programs in urban schools, which, in our opinion, reduces their heuristic potential and real impact [17]. This restriction must be overcome, which actualized the formulation of the scientific problem of organizing professional orientation of schoolchildren based on a spiritual ontological approach in this study.

\section{Methods of research}

In defining the research methodology, we use the spiritually ontological approach developed by T. I. Vlasova [18], in which teachers can include in the process of professional orientation of rural schoolchildren all spheres of life of the aggregate subjects. In this regard, the tasks that were set are as follows: justification and implementation of the model of social and pedagogical partnership in rural schools; analysis of value orientations of General stakeholders in the process of employment in a rural settlement of the Rostov region; identification of features of professional orientation of rural schoolchildren.

Base of research: small school in the Starocherkasskaya village in the Rostov region, Russian Federation. Research methods include content analysis of theoretical sources; prolonged monitoring of communication of General stakeholders in the village for 10 years; questionnaire survey; comparative analysis of respondents' questionnaires. Number of respondents and list of General stakeholders: schoolchildren - 152 people; teachers and school leaders-15 people; parents and relatives of students - 160 people; employees and managers of the Museum complex - 14 people; Ministers of worship (Orthodox cathedrals, a monastery) - 12 people; employees and heads of the municipal administration - 11 people; members of the public organization of Cossacks - 8 people.

\section{Results and discussion}

The logic of the study, first of all, implies the definition of general stakeholders in the process of professional orientation of schoolchildren in rural schools, which we refer to: schoolchildren and their families; teachers and employees of educational and cultural Centers of rural settlements; employers and heads of municipal administration. The partnership between them can be built on the basis of a spiritually ontological approach, so 
the basic indicator of partnership is trust. In this regard, let us consider the peculiarity of this phenomenon, which is typical for families that are geographically located in the space of a rural settlement. From the point of view of the economic component of the family economy, within which not only disabled family members and children work, but employed family members as well, it becomes apparent that trust is built through effective contribution of each of them to the maintenance of family farms, which can be, on the one hand, utility, on the other, may be the main source of wealth in the form of selfemployment in a situation of general decline in agricultural production in Russia. At the same time, under the conditions of reform, there was a general decline in the well-being of rural families compared to urban ones, and there was a loss of the professional and cultural status of the rural population (G. Shirokalova). However, the rural family in Russian society, becoming an intermediary between the transforming society and the individual, affects the sustainability of agriculture through the prism of its multifunctionality, performing the following functions: economic, reproductive, employment function, ecological function, biodiversity conservation function, recreational function, agro-tourism function, preservation of traditional way of life, educational and spiritual-moral function (V. Uzun). Therefore, trust in the model of social and pedagogical partnership becomes a basic indicator for organizing communication of all stakeholders in the space of the agricultural complex, being its spiritual component. At the same time, agricultural enterprises (one of the general stakeholders), legally turning into private ones, hardly change the principles of work, since they are based on kinship relations, thereby forcing the rural family to change their life strategies and values in the process of mastering market methods of social functioning. Thus, there is a need to compare the value orientations of the total subjects of professional orientation of schoolchildren, which was carried out in the conditions of a prolonged study. The influence of traditions on the modern rural family, as an independent social structure, can be traced in the presence or absence of the "institution" of the peasant court, which develops into farms. He peasant court is both a socio-economic and socio-psychological structure, united by all types of marriage and family relations marital, parental and related. In this perspective, professional orientations of children living in rural areas are also developed, and the family finds itself in self-government conditions.

When organizing professional orientation, it is necessary to rely on the theory of productive learning, in the contours of which it is possible to develop the intellectual activity of schoolchildren who act as the second general stakeholder, which implies: connection of training with the real work of the schoolchild; getting a quality product as a result of this activity; joint work. This indicates that a team of teachers and students is building a partnership. In this perspective, the main discourse is conducted around the phenomenon of "schoolchildren' interest in the subject". Based on this hypothesis, we can conclude that the more the student is passionate about, for example, natural sciences, the more likely it is that he will work in the field of agricultural production, for example. On the contrary, if a student is focused on literature as an academic subject, it should be expected that he will not return to work in the village, since it will not be possible to apply his talent in the field of writing. Unfortunately, based on such a formal approach, numerous questionnaires are compiled in psychological science, in which the authors determine not only the interest in the subject, but even the propensities of respondents to a particular field of activity, such as: "man-man", "man-nature" and others. It should be noted that the questions of these questionnaires do not take into account the situational state of young people, their existential periods of life, civil, moral and other personal attitudes of a person, which we overcame when compiling questionnaires for the study of schoolchildren professional orientation. At the same time, scientists note that along with the educational interest, it is necessary for the schoolchild to understand how much this coincides with his abilities. This coincidence is usually not always recognized and is an obstacle to the 
implementation of professional plans in the future. From this point of view, the requests of the agricultural complex and rural territory are not taken into account at all, both by respondents and by teachers ' groups, which actualizes the task of organizing a social and pedagogical partnership as a condition for professional orientation of schoolchildren with the aim of returning them to the rural settlement.

From the point of view of the socio-pedagogical approach, the rural school is considered by scientists (M. M. Plotkin, L. V. Baiborodova, 2011) as a cultural factor in the development of modern rural areas in the Russian Federation (on the example of Karelia and Stavropol territory) [19]. At the same time, this approach is limited due to the fact that in a rural settlement, if there are cultural and spiritual Centers, it is still advisable to consider them as direct stakeholders who are interested in ensuring that young people return to the village after receiving secondary or higher professional education. Whether school graduates will return to the village after professional training, whether specialists will be able to solve local economic and economic problems, depends on the participation of the specified cultural and spiritual stakeholder in the process of schoolchildren 'professional orientation, which fills the socio-pedagogical partnership with spiritual and ontological content.

Thus, based on the content analysis of theoretical sources, we have identified the spheres of life of general stakeholders, developed and implemented a model of professional orientation of schoolchildren in a small school in the Starocherkasskaya village, Rostov region. In the family and community sphere of life, schoolchildren show themselves as equal members of the family, on the one hand, on the other, they participate in community Cossack holidays, preserving the traditions of the titular people. At the same time, this is reflected in all academic disciplines in the educational process of a rural school. The spiritual and cultural sphere of life includes creative groups of schoolchildren who conduct concerts together with adult residents of the village, participate in folk festivals, competitions that unite spiritually and contribute to the expansion of the cultural space of the village, orienting students to choose a profession in the non-agricultural sector, and then return to their native home. In the professional and personal sphere of life in rural schools, on the one hand, traditional forms of familiarization with various professions are used, on the other hand, immersion in the economy of farms is purposefully carried out, including direct joint work with employers in the agricultural sector. Finally, individual sphere of life extends the application of personal aptitudes of schoolchildren along with older members of the rural family farm, thereby increasing not only their participation but also raises cooperation to the partnership level, thereby orienting young people to return to work in the agricultural sector of the economy. The model of spiritual and ontological partnership in a rural school with the designation of the main components is presented in a table 1.

Table 1. Model of spiritual ontological partnership in rural schools.

\begin{tabular}{|c|c|c|c|}
\hline \multicolumn{4}{|c|}{$\begin{array}{c}\text { Professional orientation of schoolchildren in rural schools based on social and pedagogical } \\
\text { partnership }\end{array}$} \\
\hline stakeholders & spheres of life & \multicolumn{2}{|c|}{ forms of interaction } \\
\hline Family & family and community & $\Rightarrow$ & Cossack community \\
\hline $\begin{array}{l}\text { Employers of non- } \\
\text { agricultural } \\
\text { sector }\end{array}$ & spiritual and cultural & $\Rightarrow$ & Church, monastery \\
\hline $\begin{array}{l}\text { Employers of agricultural } \\
\text { sector }\end{array}$ & professional and social & $\Rightarrow$ & Farm \\
\hline Schoolchildren & individual-personal & $\Rightarrow$ & Peasant household \\
\hline
\end{tabular}

In 2008, a small rural school introduced this model, which was gradually supplemented by other forms of interaction between stakeholders. However, the entrance (2008) and 
boundary (2018) diagnostics were conducted using the same type of author's questionnaires, which allowed comparing the results without a relatively specific reference to the respondents. The content of the questionnaires included five questions on four areas of life of general stakeholders. The sample of respondents was met quantitatively with relative quality stability (schoolchildren and their families are different, and adult workers have not changed much, including employers from both sectors of the village economy). This article presents a comparison of the aggregate results of only respondents schoolchildren - by the basic parameter "trust". The data obtained indicate that most of them in 2018 have a stable positive perception of themselves in the space of the agricultural region of Russia, which is shown on the graph (Fig. 1).

\section{Dynamics of professional orientation of schoolchildren on the "trust" parameter}

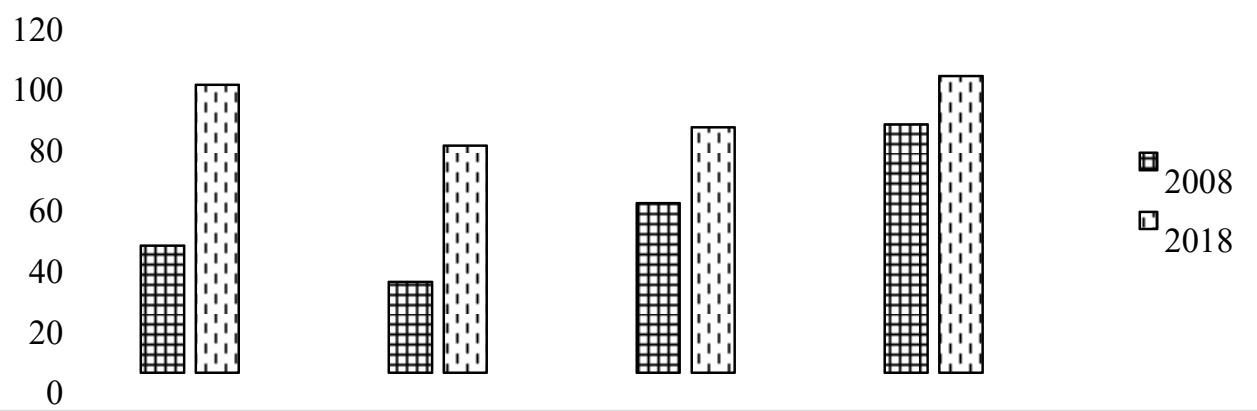

Fig. 1. The results for spheres: 1) family-community, 2) spiritual-cultural, 3) professional-social, 4) individual-personal (\%).

\section{Conclusions}

Professional orientation of schoolchildren living in an agricultural region (for example, in the Starocherkasskaya village, Rostov region) has a main goal: meeting the needs of young people in their personal and professional vocations, which should not contradict the native values of Russia. Let us list the features of this process in terms of rootedness of people living in the same rural area:

1. Relations between general stakeholders are built on the basis of trust as a spiritual component.

2. In addition to direct employers of the agricultural sector, general stakeholders should include families, cultural and spiritual structures, and schoolchildren themselves, thereby increasing the likelihood of returning specialists to the village.

3. The ontology of the rural family in Russia consists not so much in its ability to be a permanent material support, but rather to remain a moral support in any life circumstances for all family members, including the younger generation.

4. The crisis of distrust that we found in all respondents in 2008 was a reflection of the General crisis of identity, primarily social identity, since the exclusive focus on money prevailed in the field of labor to the detriment of ethnic and community interests.

5. The socio-pedagogical partnership for vocational guidance of schoolchildren showed in 2018 that most rural schoolchildren feel confident in their lives and return to work in the village, both in the agricultural and non-agricultural sectors of the economy. 


\section{References}

1. T. Vlasova, Marry Hellen Richmond's views of social partnership in American social workers 'vocational education (2016)

2. T. Vlasova, E. Krasnova, V. Abraukhova, N. Safontseva, Journal of Social Studies Education Research 9(1), 76-88 (2018)

3. T. Vlasova, V. Abraukhova, N. Mamchits, E. Egorova, ICTOPP (2019)

4. T. Vlasova, B. Meskhi, S. Smirnov, BPiKAinSM, 59-85 (2018)

5. M.R.U. Meyer, C.N.B. Hamilton, T. Prochnow and others, Preventive Medicine 129 (2019)

6. P.-Å. Rosvall, M. Rönnlund, M. Johansson, Journal of Rural Studies 60, 43-51 (2018)

7. D.P. Smith, R. Higley, Journal of Rural Studies 28, 49-55 (2018)

8. K. Sakaue, International Journal of Educational Development 62, 112-127 (2018) https://doi.org /10.1016/j.ijedudev. 2018.02.008

9. S. Dhanaraj, V. Mahambare, World Development 115, 17-29 (2019)

10. L. Xing, C. Campbell, X. Li, M. Noellert, J. Lee, Research in Social Stratification and Mobility (2020) doi: https: //doi.org/ 10.1016 /j.rssm.2019.100460

11. Y. Guo, Y. Song, Q. Chen, China Economic Review 55, 124-142 (2019)

12. L. Xing, C. Campbell, X. Li, M. Noellert, J. Lee, Research in Social Stratification and Mobility (2017) doi: https: //doi.org /10.1016 /j.rssm. 100460

13. Q. Chen, International Journal of Educational Development 54, 39-50 (2017)

14. M. Lua, X. Zhang, Economic Systems 43(2), 100694 (2019)

15. X. Chen, D. Li, X. Xu, J. Liu, R. Fu, L. Cui, S. Liu, Journal of School Psychology 72, 14-28 (2019)

16. K. Kovács, Journal of Rural Studies 28(2), 108-117 (2012) https://doi.org /10.1016/j.jrurstud.2012.01.020

17. D. Kholmogorov, Pedagogical conditions of social and professional orientation of senior pupils of rural school of agrotechnological profile (Chita, 2010) http://tsu.tmb.ru

18. T. Vlasova, Proceedings of the Volgograd state pedagogical University. Pedagogical science 1(105) (2016)

19. L. Bayborodova, Yaroslavl pedagogical Bulletin 2 (2011) 